\title{
IMPACT OF KNOWLEDGE SHARING AND ORGANIZATION INNOVATIVE CAPABILITIES ON FIRM PERFORMANCE - MEDIATING IMPACT OF CORPORATE ENTREPRENEURSHIP
}

\author{
Amna Hasnain \\ Bahauddin Zakariya University, Multan, Pakistan \\ Muhammad Sadiq Shahid \\ Bahauddin Zakariya University, Multan, Pakistan \\ M. Khuram Khalil \\ Bahauddin Zakariya University, Multan, Pakistan \\ Zeeshan Ahmad Qureshi \\ Bahauddin Zakariya University, Multan, Pakistan
}

\begin{abstract}
The main purpose of this study is to investigate the mediating impact of corporate entrepreneurship on the relationship between knowledge sharing, organizational innovational capabilities and firm performance. Rapid change in technology and the world being a global village has forced organizations to change their way of doing business. Organizations require developing new products, improving production process and capturing new markets to survive against local and international competition. Pakistani organizations are losing their market share in local and internationals markets due to their inability to meet continuously increasing customer demands. This study will helps these organizations to understand the importance of knowledge sharing, innovation and corporate entrepreneurship in their performance. The data were collected from service sector industries by using a close ended questionnaire. Results show that knowledge sharing and organizational innovative capabilities have a positive impact on firm performance while corporate entrepreneurship more strengthens this impact. It is recommended for organizations to create the knowledge sharing environment in the organization through awareness sessions and to teach employees how knowledge sharing can collectively benefit them and the organization. Organizational culture should welcome new ideas and opportunities and strive to achieve continuous excellence.
\end{abstract}

Keywords: Knowledge Sharing, Organizational Innovation Capabilities, Corporate Entrepreneurship, Firm Performance and Structure Equation Modeling

\section{Jel Classification:G30: G31,G32}

*The material presented by the author does not necessarily portray the view point of the editors and the management of the Ilma University - Formerly IBT

1. Amna Hasnain:

2. Muhammad Sadiq Shahid :

3. M. Khuram Khalil:

4. Zeeshan Ahmad Qureshi: amnahussain12@gmail.com

sshahidmalik@bzu.edu.pk

khuram.khalil@gmail.com

zeeshan_ahmed@hotmail.com

CILMA-JBS is published by the Ilma University - Formerly IBT

Main Ibrahim Hydri Road, Korangi Creek, Karachi-75190, Pakistan. 


\section{INTRODUCTION}

In today's modern world, technology is changing rapidly, so is the ways of doing business. It is essential for organizations to develop new ideas and use innovative approaches for doing business. They need to focus on innovation at different departmental and corporate level to achieve sustainable competitive advantage in the present cutthroat competitive business environment.

Knowledge has become the most important factor of success and competitiveness for any organization in the today's knowledge economy (Drucker, 1993). Knowledge sharing is an essential part of knowledge management (Choo \& AlvarengaNeto, 2010). Fastest changing technological environment and huge developments in the field of information technology has makes organizations realized the importance of knowledge sharing and provide base for investment in knowledge management system (Frappaolo, 2006). Strategies of knowledge management require the organizations to efficiently manage their intangible assets (Drucker \&Maciariello, 2008). Most valuable intangible asset for an organization is their workers which have the required knowledge and experience to make their organization successful. Finding, attracting and retaining these workers and then motivating them to share their knowledge with other organization members in order make it part of the organization practices is the key for success (Keenan \&Aggestam, 2001).

During last two decades, several forces has transformed the nature of competition in the business world (Schneckenberg et al., 2015). This rapidly changing business environment called hypercompetitive (Wang, 1997). Innovation is the key for success and sustainability in this hypercompetitive environment (Onağ et al., 2014). Introduction of innovative products in the market helps organizations in increasing their market share and gaining competitive advantage (Onağ et al., 2014). Knowledge management practice along with organizational learning and innovation capabilities can improve organization performance and success rate of newly introduced produced and service in the market (Schneckenberg et al., 2015).

The popular concept in the modern world, use to measure the firms entrepreneurial performance, is known as corporate entrepreneurship. Corporate entrepreneurship is a process of actively searching and exploiting previously unknown opportunities (Teng, 2007). When going through rough times and losing customers and profits to competitors, organization uses corporate entrepreneurship as a survival technique. But, this process could be frighten and hold the risk same as starting a new venture. It is mostly because an organization could consciously measure the pro and cons of each available opportunity but the outcome of innovation is not predictable (Phan et al., 2009). On the other hand, if corporate entrepreneurship implemented successfully, it have great potential to promote and sustain organizational performance. Firms that successfully implement corporate entrepreneurship are considered flexible, dynamic and long lasting by the investors due to their ability to find and take advantage of hidden opportunities (Kuratko, Goldsby, \& Hornsby, 2012).

Concept of corporate entrepreneurship is unrecognized in the Pakistan and there are limited studies of knowledge sharing in Pakistani context. Pakistani corporations are losing their market share due to intense local and international competition. They required to improve their products and renovate their organization, if necessary, to compete with multinational corporations. This study will contribute to the recognition process of the corporate entrepreneurship concept in the country and will help corporations to relate their knowledge 
sharing and innovation activities to corporate entrepreneurship and understand its link with their performance.

\section{MATERIALS AND METHODS}

In this section, we will have an overview of pervious literature in the field of Knowledge management, Organizational innovation capabilities and corporate entrepreneurship and later will discuss the methods of analysis used in this research.

\section{KNOWLEDGE SHARING}

Successful organizations in this rapidly changing knowledge economy update their knowledge assets constantly (Cooper, 2001). Historically, goods were produced by exploiting natural resources and competitive advantage was depending upon skills of the producer. The knowledge required to produce those goods was considered confidential and shared from father to son and from masters to his students. During Industrial revolution, products quality was improved and goods were available at low prices. Industries were using machinery and technology to improve the efficiency of production process. Workers perform routine activities daily and knowledge available to workers was limited only to their work. Complete knowledge was limited to upper management and specialists only. During last 50 years, introduction of IT change the ways of business and provide opportunities for interdepartmental communication and closure control of different departments. During the last decade, organizations realize the importance of knowledge and intellectual capital and its impact on firm performance. This realization starts a movement to make strategies for knowledge management (Crawford et al., 2009).

Initial theories were mostly based upon the process of codifying knowledge which means that identifying knowledge that employees essentially required to be familiar with and need to share with new employees so they can replace them when the time comes. Agerfalk et al., (2005) criticize these approaches and state that behavioral aspect of team members, their informal chat and their face-to-face interaction have major importance in the success of knowledge sharing in any organization (Agerfalk et al., 2005). When employees trust each other and their social bonding increase, it increases the chances that they will willingly enter in knowledge sharing process (Hinds \& McGrath, 2006).

Researchers identified 4 major characteristic or conditions of team members that helps in improving knowledge sharing in a group. First is Social and behavioral characteristics of team which means how much team members trust on each other, have the ability to conduct open dialogue and can ask each other frequent question to develop their understanding. Second is Epistemic attributes which means the common knowledge share by the team members, their shared values and combine efforts to achieve same objectives. Third characteristic is the organizational structure which is the measurement of upper management willingness to improve knowledge sharing in the organization. It means how much upper management is willing to empower team members to make their own decisions and use leadership style for managing and guiding teams. Forth characteristics helps in the improvement of knowledge management is the information and communication system exist in the organization. It means that if organization have adopted formal communication process, it could affect their chances of success to achieve knowledge sharing environment.(Choo \& AlvarengaNeto, 2010). 


\section{KNOWLEDGE SHARING AND FIRM PERFORMANCE}

Studies show that knowledge sharing increase competitive capabilities that can generate greater success for the organization. Knowledge sharing can generate synergistic results better than any individual can achieve alone (Ipe, 2003). Studies also show that knowledge sharing among employees can improve response time to customer complaints and requirements and reduce the cost of operations (Sher \& Lee, 2004). In knowledge sharing culture, employees share their knowledge and experience which improve firm overall learning and innovation capabilities which then lead to operation efficiency and greater strategic benefits (Law \& Ngai, 2008).

Wang \& Wang (2012) conduct a quantitative study to investigate the relationship between knowledge sharing, innovation and firm performance in 89 technology firms of Jiangsu, China. Results found that both tacit and explicit knowledge have positive impact on firm performance. Results also shows that knowledge sharing encourages innovation but this impact is stronger for tacit knowledge sharing as compare to explicit knowledge sharing.

Law \& Ngai (2008) examine the relationship between knowledge sharing and firm performance while using business process improvement, and product and service offerings as mediating variables. Data was collected from 134 companies and results shows that knowledge sharing has a significant positive impact on process improvement, and product and service offerings which then positively impact firm performance.

On the basis of previous studies and theoretical literature, we hypnotized that knowledge sharing provide base for the successful implementation of corporate entrepreneurship and have positive significant impact on firm performance.

H1: There is a relationship between knowledge sharing and corporate entrepreneurship.

H2: There is a relationship between knowledge sharing and firm performance.

\section{ORGANIZATIONAL INNOVATION CAPABILITIES}

Innovation simply means the organization ability to adapt itself according to business environment (Ekvall, 1996). Organization innovation capabilities means the overall capability of an organization to introduce new products in the existing market or introducing existing products in the new markets by combining its strategic and innovative capabilities (Wang \& Ahmed, 2004).

The term innovation capability or innovativeness was first used by Burns and Stalker in 1961. They define innovativeness as the ability of an organization to implement or adopt new ideas, process or products (Burns and Stalker, 1961). The theory of innovation specifically related to our study is called diffusion of innovation. Diffusion of innovation was first defined by Rogers in 1962 who defined the concept as the process of communication use to communicate innovation through different channels among member of the organization or social circle (Rogers, 1962; 2003). Though diffusion of innovation studies were started with the focus on individual consumers about their response towards new products and their adoption behaviour but eventually they broadened their horizon and start studying the organizations openness to change and adoption of new ideas and technology (Hurley \&Hult, 
1998). There are five classification for the diffusion of innovation staring from innovators, followed by the early adopters, the early majority, the late majority and the laggards. According to Rogers, there are only $2.5 \%$ of organizations that fall in the category of innovators (Rogers, 2003). These $2.5 \%$ are the real market leaders due to their ability to recognize useful opportunities and took their advantage before their competitors. Isaksen \& Ekvall (2007) consider organizational innovativeness as the ability of an organization to being the first to adopt the technology and took advantage of changing environment (Isaksen \& Ekvall, 2007).

\section{ORGANIZATIONAL INNOVATION CAPABILITIES AND FIRM PERFORMANCE}

Innovation capabilities enable an organization to offer greater variety of rare, valuable and differentiated products which give firm competitive advantage and lead to higher financial performance (Zahra et al., 2000). Camisón\&Villar-López (2014) use resource based view to study this relationship, and find that innovation capabilities are the source of competitive advantage which lead to immediate increase in firm performance. Sustainable competitive advantage deeply relies on the firm capability to innovate, adopt with environment and recognize resources and opportunities from external environment.

Biedenbach\& Müller (2012) try to find the impact of firm absorptive, innovation and adaption capabilities on its performance in pharmaceutical and biotechnology industries of Sweden. Study collect data through questionnaire and interviews and finds that absorptive, innovative and adaptive capabilities have positive relationship with firm short term and long term performance.

Sher \& Yang (2005) try to investigate the relationship between innovation capabilities, research and development practices and firm performance in integrated circuit industry of Taiwan Stock Exchange. This study is significant because it measure firm performance on the base of return on asset, return on sale and return on equity unlike previous studies where performance was measured through questionnaire. The results show that innovation capabilities have positive impact on firm performance.

We are trying to understand following relationships in service sector of Pakistan and on the basis of previous literature; we are hypnotizing that these relationships will be positive.

H3: There is a relationship between organizational innovative capabilities and corporate entrepreneurship.

H4: There is a relationship between organizational innovative capabilities and firm performance.

\section{CORPORATE ENTREPRENEURSHIP AND ORGANIZATIONAL PERFORMANCE}

There are 2 basic components of CE that have significant impact on firm performance which are: strategic renewal and corporate venturing. Strategic renewal consists of activities used to redefine the company vision, mission, and competitive approach that help the company to adapt with continuously changing environment (Russell, 1999). By using strategic renewal, firms come in better position to take advantages from opportunities and tackle threats in the external environment. It means that strategic renewal allow a company to 
adopt a most suitable business structure according to current environmental conditions and react effectively in case of any change in environmental conditions (Zhou et al., 2005). Corporate venturing enhances firm performance in two ways either by extending the current business structure or by diversifying the current business portfolio. Business invest in new business, to achieve extension in current business structure, that are to some extent match with firm current target market and products and can easily integrate in the current business of parent company. Similarities in existing and new business provide opportunities to use existing knowledge and resources of the organization to sustain and make successful the new business, which will eventually increase the organizational overall performance. Organization achieves diversification by investing in ventures that are different from existing business of the parent company (Lin \& Lee, 2011). Diversification in business ventures enable organization to took advantages of opportunities from different sector of the environment. Diversification, if handled effectively, can increase firm chances of survival and increase firm overall performance (Simsek\&Heavey, 2011).

Bierwerth et al.,(2015) done a comprehensive study to understand the relationship between corporate entrepreneurship and firm performance by using data from 13,237 firms from North America, Europe and Asia. They used strategic renewal, innovation and corporate venturing as the variable for corporate entrepreneurship. Results show that all variable of corporate entrepreneurship have significant positive impact on firm performance. Results also show that this relationship is strongest in Europe as compare to Asia and North America.

Özdemirci(2011) conduct the study to measure the impact of corporate entrepreneurship and strategic leadership style on firm performance by using data from 12000 members of Istanbul Chamber of Industry. Innovativeness, self-renewal, pro-activeness and new business venturing are used as the variable for corporate entrepreneurship and performance is measured as concrete and abstract. Results show that only new business venturing has significant impact on firm concrete performance while Innovativeness, self-renewal, and new business venturing have significant impact on abstract performance. Pro-activeness does not have any significant impact on either type of performance.

In our study, we are using corporate entrepreneurship as a mediating variable and supposing that corporate entrepreneurship strengthen the positive impact of knowledge sharing and organizational innovation capabilities on firm performance.

H5: Corporate entrepreneurship has significant impact on organizational performance.

H6: Corporate entrepreneurship positively mediates the impact of knowledge sharing and organizational innovation capabilities on firm performance.

To achieve the goals of this study, we collect data through closed ended questionnaire, which consist of 22 questions that measure our 4 variables, with 5 point Likert scale. We have used simple random sampling for data collection. Our population consists of all service sector companies located in Punjab. Total 600 questionnaires were distributed out of which 483 complete questionnaire were received back and used for this study. Knowledge Sharing and Organizational Innovation Capabilities are the independent variables and firm performance is the dependent variable in this study while Corporate Entrepreneurship works as mediating variable in the relationship. 


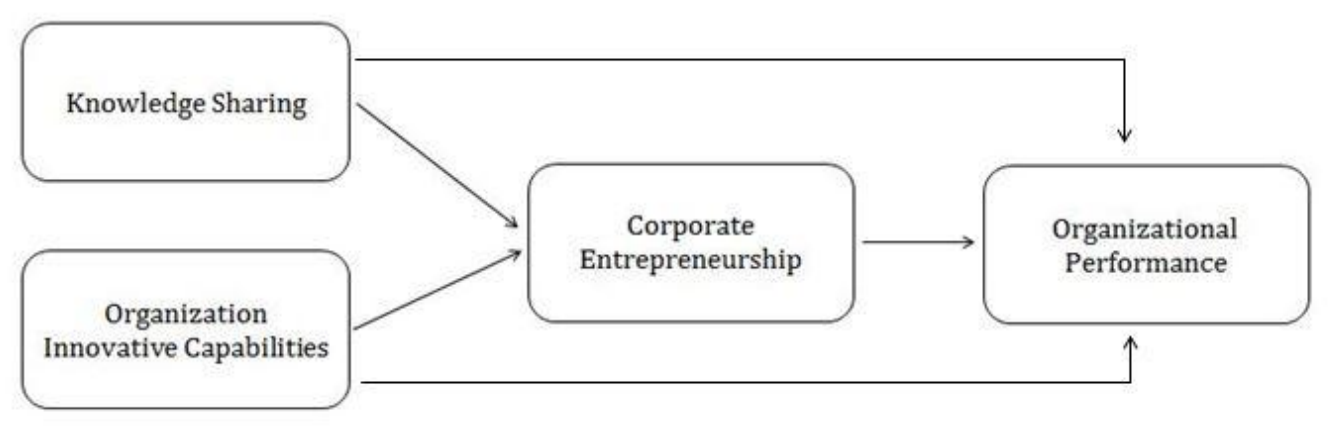

Structure equation modeling used to perform the analysis because it has become the most popular analysis technique in various fields especially in the field of social sciences (Hooper et al., 2008). PLS-SEM method is popular due to its features that can measure the interrelationship between various variables simultaneously. It offers a substitute method of Co-variance based structure equation modeling (CB-SEM) (Jöreskog, 1978). PLS-SEM have the ability to estimate complex models. PLS is normally more suitable to use when research include multiple variables and complex model (Hair Jr et al., 2013). Sarkar et al.,(2001) suggest that PLS-SEM can provide solid base for theory confirmation and its results helps in explaining the theory applications.

\section{EMPIRICAL RESULTS}

First, we used Cronbach's Alpha to check the reliability of the collected data and the results for each variable are above $70 \%$, which is considered satisfactory.

Table 01; Cronbach's Alpha

\begin{tabular}{|l|l|}
\hline Variables & Cronbach's Alpha Values \\
\hline Corporate Entrepreneurship & 0.714 \\
\hline Knowledge Sharing & 0.752 \\
\hline Organization Innovative Capabilities & 0.758 \\
\hline Organizational Performance & 0.829 \\
\hline
\end{tabular}

Table 02; Pearson Correlation Analysis

\begin{tabular}{|l|l|l|l|}
\hline Variables & $\begin{array}{l}\text { Corporate } \\
\text { Entrepreneurship }\end{array}$ & $\begin{array}{l}\text { Knowledge } \\
\text { Sharing }\end{array}$ & $\begin{array}{l}\text { Organization } \\
\text { Innovative Capabilities }\end{array}$ \\
\hline Knowledge Sharing & 0.498 & $\mathbf{1}$ & \\
\hline $\begin{array}{l}\text { Organization Innovative } \\
\text { Capabilities }\end{array}$ & 0.484 & 0.525 & $\mathbf{1}$ \\
\hline Organizational Performance & 0.483 & 0.499 & 0.667 \\
\hline
\end{tabular}

The correlation between independent, dependent and mediating variables result shows that correlation lies between 0.483 and 0.667 which shows that correlation our variables is moderate.

Further, Structural equation modeling used to measures the relationship between given variables of the system. Table 3 shows the results of beta, $t$-value and p-value for each relationship. This table is called direct relationship table in Structural equation modeling. 


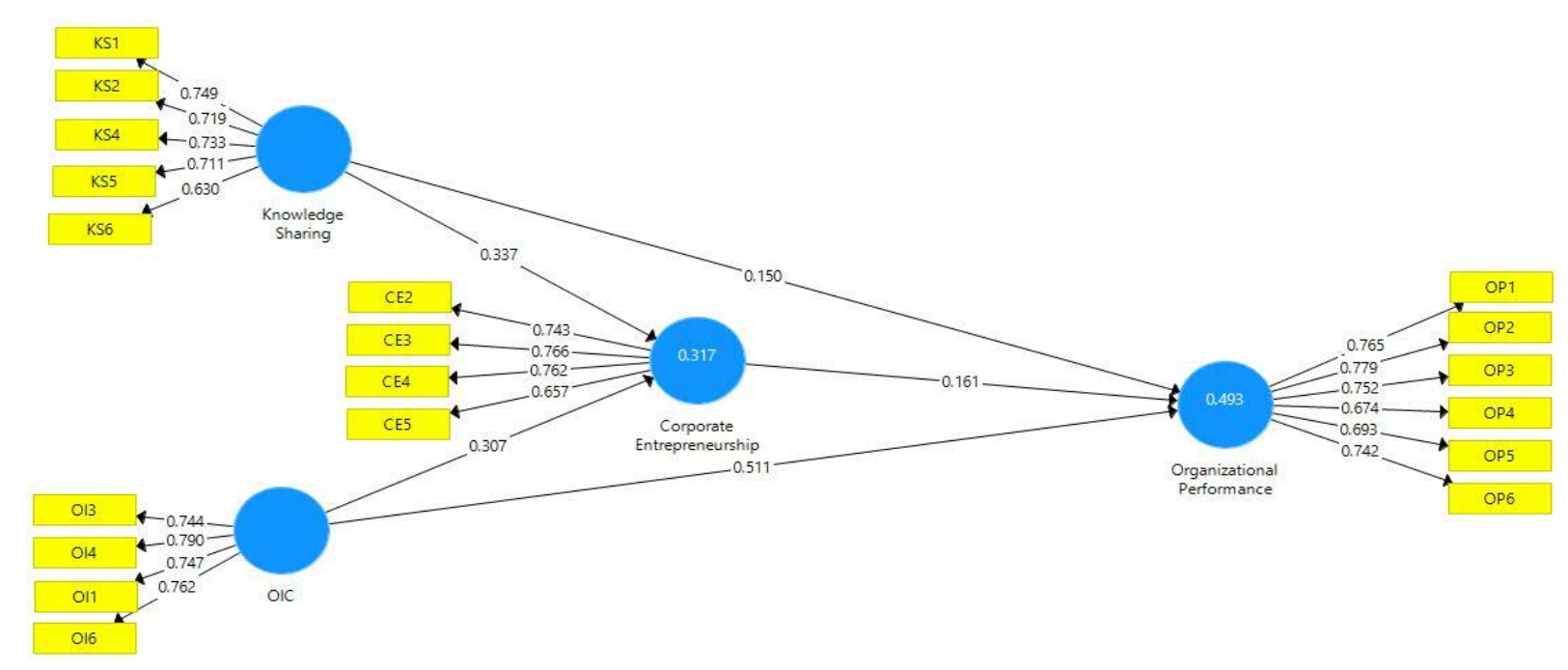

Table 3: Direct Relationship

\begin{tabular}{|l|l|l|l|l|l|}
\hline Relationships & Beta Value & Mean & Std., Error & T-Statistics & P-Value \\
\hline KS and CE & 0.161 & 0.160 & 0.046 & 3.471 & 0.001 \\
\hline KS and OP & 0.337 & 0.337 & 0.044 & 7.749 & 0.000 \\
\hline OIC and CE & 0.150 & 0.148 & 0.045 & 3.328 & 0.001 \\
\hline OIC and Op & 0.307 & 0.310 & 0.044 & 7.046 & 0.000 \\
\hline CE and OP & 0.511 & 0.513 & 0.040 & 12.82 & 0.000 \\
\hline
\end{tabular}

The direct relationship table results show that all relationships are positively significant. Further, Sobel(1982) test two tail probability test used to measure the mediation impact of corporate entrepreneurship on our model. Table 04 shows the result of Sobel test.

Table4: Sobel Test for mediation impact of variables

\begin{tabular}{|l|l|l|l|}
\hline Relationship Sobel Test Value & P-Value & Assessment \\
\hline $\begin{array}{l}\text { Knowledge Sharing- Corporate } \\
\text { Entrepreneurship-Organization Performance }\end{array}$ & 8.2563 & 0.0000 & Significant \\
\hline $\begin{array}{l}\text { Organizational Innovation Capabilities- } \\
\text { Corporate Entrepreneurship-Organization } \\
\text { Performance }\end{array}$ & 8.2983 & 0.0000 & Significant \\
\hline
\end{tabular}

\section{DISCUSSION}

Relationship between knowledge sharing and corporate entrepreneurship has beta value of 0.161 and $p$-value of 0.001 . It means that Knowledge sharing behavior of managers and employees can provide critical information and innovative ideas to solve problems. It can also provide ideas for new product development and ideas for improvement in procedures to save time and cost. Knowledge sharing creates an open environment and makes way for collective learning for employees and enormous benefit for organization.

Relationship between knowledge sharing and organizational performance is positively significant in nature because of having $\mathrm{p}$-value of 0.0000 and beta value of 0.337 . This result matches with the results of previous studies (Wang \& Wang, 2012; Law \& Ngai, 2008). 
Result shows that Knowledge sharing improves the combine capabilities of the organization human resource that can generate success and better results for the organization (Ipe, 2003). Knowledge sharing can help in decreasing customer response time, operations cost and production time which all lead to better competitive position for the organization.

Organizational innovative capabilities have significantly positive impact on corporate entrepreneurship. According to our best knowledge, this relationship is not discussed before in any theoretical or empirical study. Corporate entrepreneurship is the gigantic form of innovation. Organization which have open culture for innovation and welcome new ideas, no matter how stupid they sound, have the ability to completely renew themselves to survive. Innovation is a common practice and essential for successful organization. Organizations who always try to find more innovative way of production or innovative ideas for new products can also take risk to implement organization level changes.

Organizational performance is also significantly impacted by Organizational innovative capabilities which match with the results of the previous studies (Camisón \& Villar-López, 2014; Biedenbach\& Müller, 2012; Sher \& Yang, 2005). Innovation capabilities enable organizations to offer valuable and rare product range which increase customer's satisfaction and loyalty, provide competitive advantage and lead to greater financial performance. In this throat cutting competitive business environment, providing innovative products which fulfill more needs of the customers than competitive products available in the market at lowest possible price is the key for success for any organization. Innovation capabilities help the organization to achieve these conditions of survival.

Results of Sobel test results show that knowledge sharing and innovation capabilities have a positive impact on organizational performance and corporate entrepreneurship. We were trying to find the mediating impact of corporate entrepreneurship on the relationship between knowledge sharing, innovation capabilities and performance. Results of Sobel test shows that corporate entrepreneurship improves the impact of knowledge sharing and innovation capabilities on firm performance.

Previous studies found that knowledge sharing impact on performance improved by using innovation capabilities as mediator in the relationship. Knowledge sharing improves the firm ability to innovative and firm having experience of innovation can successfully applied corporate entrepreneurship. Corporate entrepreneurship, if applied successfully, can have tremendous impact on firm performance and provide enormous competitive advantage for the organization.

\section{CONCLUSION}

Previous studies and our findings show that knowledge sharing has tremendous impact on firm performance. Knowledge sharing provides opportunities for collective learning, innovative ideas for new products and innovative changes in the production process to reduce cost. Studies found that organizations commonly face reservation from employees for sharing their knowledge. Organizations need to arrange awareness sessions for the employees and teach them how knowledge sharing can collectively benefit them and the organization. Organizations can also use financial rewards for motivating employees to engage in knowledge sharing behavior and converting their knowledge into organization practices. 
Another important recommendation our study provide to managers is to activity engage in innovation activities. Employees need to be ensured that their ideas are welcomed and appreciated by the upper management. Organization should create an open culture where people feel free to share their ideas with others. Organization should also provide proper appreciation and reward for employees who ideas are used by the organization. This practice will encourage other employees to share their ideas. This will provide the organization with sustainable innovation which, with little effort, is easy to execute and can provide competitive advantage for the organization.

In specific conditions, only sustainable innovation is not enough for the success of the organization. In these cases, organizations used disruptive innovation which requires complete change of products or procedures and, in extreme cases, renewal of the whole organization. Managers need to understand their business environment and need appropriate innovation for the organization. If organization need complete renewal, then managers need to take every stakeholder on board and use their ideas and utilize their participation while using their experience of sustainable innovation. If organizations are able to apply corporate entrepreneurship efficiently and effectively, they can survive the worst economic conditions and become market leader.

There is always room for improvement. Our study also has some limitations which can reduced by the future researchers to make the findings more valid and reliable. Due to time and financial restrains, we collect data only from limited number of service sectors companies which located in big cities (Multan, Lahore, Faisalabad and Rawalpindi) of Punjab, which make our findings limited to service sector of Punjab only. We used adopted questionnaire which was originally designed for collecting data from European companies. It means that our questionnaire may have the cultural element missing. Future researchers can develop questionnaire with having Pakistani culture in mind or could also use other data collection techniques like focus group or interviews and repeat this study for other industrial sectors.

\section{REFERENCES}

Agerfalk, J., Fitzgerald, B., Holmstrom Olsson, H., Lings, B., Lundell, B., \& Ó Conchúir, E. (2005). A framework for considering opportunities and threats in distributed software development.

Biedenbach, T., \& Müller, R. (2012). Absorptive, innovative and adaptive capabilities and their impact on project and project portfolio performance. International Journal of Project Management , 30 (5), 621-635.

Bierwerth, M., Schwens, C., Isidor, R., \&Kabst, R. (2015). Corporate entrepreneurship and performance: A meta-analysis. Small Business Economics, 1-24.

Burns, T., \& Stalker, G. M. (1961). The management of innovation. London, UK: Tavistock Publications.

Camisón, C., \&Villar-López, A. (2014). Organizational innovation as an enabler of technological innovation capabilities and firm performance. Journal of Business Research, 67 (1), 2891-2902.

Cooper, R. G. (2001). Winning at new products: Accelerating the process from idea to launch. Cambridge: Perseus Publishing.

Crawford, K., Hasan, H., Warne, L., \& Linger, H. (2009). From traditional knowledge management in hierarchical organizations to a network centric paradigm for a changing world. Emergence: Complexity and Organization, 11(1), 1.

Drucker, P. F. (1993). Post Capitalist Society. London: Butterworth Heinemann, Oxford. 
Drucker, P. F., \&Maciariello, J. A. (2008). Management (Rev. ed.). New York, NY: Collins.

Ekvall, G. (1996). Organizational climate for creativity and innovation. European Journal of Work and Organizational Psychology, 5(1), 105-123.

Frappaolo, C. (2006). Knowledge management. West Sussex, England: Capstone.

Hair, J. F., Sarstedt, M., Ringle, C. M., \& Mena, J. A. (2012). An assessment of the use of partial least squares structural equation modeling in marketing research. Journal of the academy of marketing science, 40(3), 414-433.

Hinds, P., \& McGrath, C. (2006). Structures that work: social structure, work structure and coordination ease in geographically distributed teams. In Proceedings of the 2006 20th anniversary conference on Computer supported cooperative work (pp. 343-352) ACM.

Hooper, D., Coughlan, J., \& Mullen, M. (2008). Structural equation modelling: Guidelines for determining model fit. Journal of Business Research, 6(1), 53-60.

Hurley, R. F., \&Hult, G. T. M. (1998). Innovation, market orientation, and organizational learning: an integration and empirical examination. The Journal of Marketing, 42-54.

Isaksen, S. G., \&Ekvall, G. (2007). Assessing the context for change: A technical manual for the Situational Outlook Questionnaire. The Creative Problem Solving Group. Orchard Park, New York.

Ipe, M. (2003). Knowledge sharing in organizations: A conceptual framework. Human Resource Development Review , 2 (4), 337-359.

Jöreskog, K. G. (1978). Structural analysis of covariance and correlation matrices. Psychometrika, 43(4), 443-477.

Keenan, J., \&Aggestam, M. (2001). Corporate governance and intellectual capital some conceptualisations. Corporate Governance: An International Review , 9 (4), 259-275.

Kuratko, D. F., Goldsby, M. G., \& Hornsby, J. S. (2012). Innovation acceleration: Transforming organizational thinking. Upper Saddle River, NJ: Pearson/Prentice Hall.

Law, C. C., \& Ngai, E. W. (2008). An empirical study of the effects of knowledge sharing and learning behaviors on firm performance. Expert Systems with Applications , 34 (4), 2342-2349.

Lin, S. J., \& Lee, J. R. (2011). Configuring a corporate venturing portfolio to create growth value: Within-portfolio diversity and strategic linkage. Journal of Business Venturing , 26 (4), 489-503.

Onağ, A. O., Tepeci, M., \&Ba ${ }^{\circ} a l p$, A. A. (2014). Organizational Learning Capability and its Impact on Firm Innovativeness. Procedia-Social and Behavioral Sciences, 150, 708717.

Özdemirci, A. (2011). Corporate entrepreneurship and strategy process: A performance based research on Istanbul market. Procedia-Social and Behavioral Sciences, 24, 611-626.

Phan, P. H., Wright, M., Ucbasaran, D., \& Tan, W. L. (2009). Corporate entrepreneurship: Current research and future directions. Journal of Business Venturing , 24 (3), 197205.

Rogers, E. M. (1962). Diffusion of innovation. New York, NY: Free Press.

Rogers, E. M. (2003). Diffusion of innovation, $5^{\text {th }}$ ed., New York, NY: Free Press.

Russell, R. D. (1999). Developing a process model of intrapreneurial systems: A cognitive mapping approach. Theory and Practice , 23 (3), 65-65.

Sarkar, M. B., Echambadi, R., Cavusgil, S. T., \&Aulakh, P. S. (2001). The influence of complementarity, compatibility, and relationship capital on alliance performance. Journal of the academy of marketing science, 29(4), 358-373.

Schneckenberg, D., Truong, Y., \&Mazloomi, H. (2015). Microfoundations of innovative capabilities: The leverage of collaborative technologies on organizational learning and 
knowledge management in a multinational corporation. Technological Forecasting and Social Change, 100, 356-368.

Sher, P. J., \& Lee, V. C. (2004). Information technology as a facilitator for enhancing dynamic capabilities through knowledge management. Information \&Management, 41, 933-945.

Sher, J., \& Yang, Y. (2005). The effects of innovative capabilities and R\&D clustering on firm performance: the evidence of Taiwan's semiconductor industry. Technovation , 25 (1), 33-43.

Simsek, Z., \&Heavey, C. (2011). The mediating role of knowledge-based capital for corporate entrepreneurship effects on performance: A study of small-to medium-sized firms. Strategic Entrepreneurship Journal , 5 (1), 81-100.

Sobel, M. E. (1982). Asymptotic confidence intervals for indirect effects in structural equation models. Sociological methodology , 13, 290-312.

Teng, B. S. (2007). Corporate Entrepreneurship Activities through Strategic Alliances: A Resource-Based Approach toward Competitive Advantage. Journal of Management Studies, 44(1), 119-142.

Wang, C. L., \& Ahmed, P. K. (2004). The development and validation of the organizational innovativeness construct using confirmatory factor analysis. European Journal of Innovation Management, 7(4), 303-313.

Wang, Q. (1997). R\&D/marketing interface in a firm's capability-building process: evidence from pharmaceutical firms. International Journal of Innovation Management , 1 (1), 23-52.

Wang, Z., \& Wang, N. (2012). Knowledge sharing, innovation and firm performance. Expert systems with applications , 39 (10), 8899-8908.

Wei Choo, C., \& Correa Drummond de AlvarengaNeto, R. (2010). Beyond the ba: managing enabling contexts in knowledge organizations. Journal of Knowledge Management, 14(4), 592-610.

Wold, H. Estimation of principal components and related models by iterative least squares.

Multivariate Analysis. Edited by: Krishnaiaah PR. 1966.

Wold, H. (1982). Soft Modeling: Intermediate between Traditional Model Building and Data Analysis. Mathematical Statistics , 6, 333-346.

Wold, H. (1985). Partial Least Squares. In S Kotz, NL Johnson. Encyclopedia of Statistical Sciences , 6, 581-591.

Zahra, S., Ireland, R., \&Hitt, M. (2000). International expansion by new venture firms: international diversity, mode of market entry, technology learning, and performance. Academy of Management Journal , 43 (5), 925-950.

Zhou, K. Z., Yim, C. K., \&Tse, D. K. (2005). The effects of strategic orientations on technology-and market-based breakthrough innovations. Journal of marketing, 69(2), 42-60. 